\title{
PHYTOSOCIOLOGY OF ANGIOSPERMS IN A HIGHLY-FRAGMENTED LANDSCAPE OF COASTAL ATLANTIC FOREST IN NORTHEASTERN BRAZIL
}

\author{
FITOSSOCIOLOGIA DE ANGIOSPERMAS EM UMA PAISAGEM \\ FRAGMENTADA DA FLORESTA ATLÂNTICA LITORÂNEA NO NORDESTE DO BRASIL
}

\author{
João Pedro Souza-Alves ${ }^{*}$ \\ Wm. Wayt Thomas ${ }^{2}$
}

Maria Regina de V. Barbosa ${ }^{3}$

\begin{abstract}
Habitat loss and fragmentation in the Atlantic forest of northeastern Brazil has been extremely extensive since colonial period leaving only small and isolated forests. Phytosociological studies are important because help to understand the vegetation structure and allow to verify what is the conservation level of habitats. In this study, we evaluated phytosociological parameters of trees and lianas from coastal Atlantic forest fragments in Sergipe, northeastern Brazil. Two sites, Fazenda Trapsa (14 ha) and, Mata do Junco Wildlife Refuge ( $522 \mathrm{ha}$ ), were studied based on protocol pattern of sampling. Fazenda Trapsa presented a higher density of trees and lianas, while in Mata do Junco the trees and lianas were taller and larger. For both sites, Eschweleira ovata was the tree species with highest importance value; the lianas Adenocalymma comosum and Coccoloba lucidula achieved the highest importance values at Fazenda Trapsa, and Davilla kunthii at Mata do Junco. In the light of these results, the vegetation in Fazenda Trapsa appears to be in an early stage of regeneration, whereas the vegetation structure of Mata do Junco indicates a more mature stage. The application of effective conservation and management strategies in these habitats can contribute to improve their structural quality.
\end{abstract}

Keywords: trees, lianas, conservation units, anthropic disturbances, Sergipe.

\section{Resumo}

A perda e fragmentação de hábitat na Mata Atlântica do nordeste do Brasil tem sido extremamente extensa desde o período colonial, restando apenas pequenos e isolados fragmentos. Estudos fitossociológicos são importantes porque auxiliam na

\footnotetext{
1 Programa de Pós-graduação em Ciências Biológicas, Departamento de Sistemática e Ecologia, Universidade Federal da Paraíba, Cidade Universitária, CEP 58059-90o. João Pessoa, Paraíba (PB), Brazil. Programa de Pós-graduação em Biologia Animal, Departamento de Zoologia, Universidade Federal de Pernambuco, Recife, Pernambuco, Av. Prof. Moraes Rego, CEP 50670-901. Recife, Pernambuco (PE), Brazil. Orcid number: oooo-0oo2-8517-1276

"Corresponding author: João Pedro Souza-Alves, e-mail: souzaalves1982@gmail.com

2 The New York Botanical Garden, Bronx, New York, 10458-5126, United States of America. Orcid number: ooo-0oo2-4996-536X

3 Universidade Federal da Paraíba, Departamento de Sistemática e Ecologia, Caixa Postal 5065, Cidade Universitária, CEP 58051-970. João Pessoa, Paraíba (PB), Brazil. Orcid number: oooo-ooo1-6166-3922
} 
compreensão da estrutura florestal e permitem verificar qual o nível de conservação dos hábitats. Neste estudo, avaliamos os parâmetros fitossociológicos de árvores e lianas em fragmentos de Mata Atlântica em Sergipe, Nordeste do Brasil. Duas áreas, Fazenda Trapsa (14 ha) e Refúgio de Vida Silvestre Mata do Junco (522 ha), foram estudados a partir do protocolo padrão de amostragem. A Fazenda Trapsa apresentou maior densidade de árvores e lianas, enquanto na Mata do Junco as árvores e lianas são mais altas e largas. Para ambos os locais, Eschweleira ovata foi a espécie arbórea com maior valor de importância; as lianas Adenocalymma comosum e Coccoloba lucidula obtiveram os mais altos valores de importância na Fazenda Trapsa, e Davilla kunthii na Mata do Junco. À luz desses resultados, a Fazenda Trapsa parece estar em um estágio inicial de regeneração, enquanto a estrutura da Mata do Junco indica um estágio mais maduro. A aplicação de estratégias eficazes de conservação e manejo desses habitats pode contribuir para melhorar sua qualidade estrutural.

Palavras-chave: árvores, lianas, Unidades de Conservação, perturbação antrópica, Sergipe.

\section{INTRODUCTION}

Destruction and degradation of natural ecosystems are the main causes of the decline of global biodiversity (Rands et al. 2010). Such actions usually result in habitat loss and fragmentation (Laurence 2010). Although small and isolated fragments act as a refuge for much of the local and regional biodiversity (small mammals: Pardini et al. 2005; amphibians and reptiles: Bell and Donnelly 2006; plants: Arroyo-Rodríguez et al. 2009), the effects of these events have led to loss of biodiversity, decreasing in biomass and modification of nutrient cycles (Haddad et al. 2015). The consequences of these processes may vary from immediate (behavioral and physiological changes) to genetic and phenotypic modifications (Galetti and Dirzo 2013), having a cascade effect on other organisms, especially plant communities (Kurten 2013).

Tropical forests maintain most of global biological diversity, presenting a structural complexity that favors the existence of many ecological niches (Whitmore 1998). The Brazilian Atlantic forest is one of the great pluvial forests of the Americas, originally covering ca. 150 million hectares in highly heterogeneous environmental conditions, with a latitudinal extension around $29^{\circ}$, extending between tropical and subtropical regions. These geographical features, combined with a wide altitudinal gradient, have favored high diversity and endemism, including more than 15,000 plant species, even though there are still a high number of species to be described (Flora do Brasil 2020 under construction). The flora and fauna of the Atlantic forest may include $1-8 \%$ of all species in the world (Silva and Casteleti 2003), even though only $28 \%$ of its original vegetation cover remains (Rezende et al. 2018), mostly composed of fragmented areas.

Most of the Atlantic forest fragments are small (<100 ha), isolated and composed primarily of secondary-growth vegetation in initial to medium succession 
stages (Melo et al. 2007; Santo-Silva et al. 2013; Joly et al. 2014). They present, however, a high species richness and if inserted in a matrix with a low level of deforestation may be of great importance for conservation, mainly on a regional scale (ArroyoRodríguez et al. 2009). The few forest fragments considered large, survive in places where human occupation is difficult (Broadbent et al. 2008). Nowadays, habitat loss and fragmentation have destroyed a large proportion of forests with rich biodiversity, causing endangered species to become extinct (see Parker et al. 1996; Stotz et al. 1996; Goerck 1997). These factors added to high endemism and high species richness have inserted the Atlantic forest as one of 34 priority regions (hotspots) for the conservation of global biological diversity, areas that shelter more than $60 \%$ of terrestrial species on the planet, but represent only $1.4 \%$ of the land surface (Mittermeier et al. 2004).

Understanding as the plant communities are structured (density, frequency and dominance of species) in small and isolated fragments is essential to apply effective conservation and management strategies. These data allow us to feature the spatial distribution of each species and verify what is the conservation status of each habitat (Felfili and Rezende 2003). In this sense, this study aimed to verify the phytosociological parameters of trees and lianas in two coastal Atlantic Forest fragments in the Brazilian State of Sergipe, where the threatened primates CoimbraFilho's titi monkey (Callicebus coimbrai) and yellow-breasted capuchin (Sapajus xanthosternos) are present.

\section{MATERIAL AND METHODS}

\section{Study area}

The study was conducted in two coastal Atlantic Forest sites in Sergipe, Brazil (Figure 1). The first site is a private property known as Fazenda Trapsa - FT (11ํㅜㄹ' $\mathrm{S}$, $37^{\circ} 14^{\prime} \mathrm{W}$ ), located in the municipality of Itaporanga d'Ajuda, southern Sergipe. This area comprises six fragments of different sizes, shapes and degree of connectivity with approximately 600 ha total forested area. This site is immersed within a matrix of pasture, anthropogenic (selective and indiscriminate logging). The second area is the Mata do Junco Wildlife Refuge - MJ (10³2'S, $\left.37^{\circ}{ }^{\circ} 3^{\prime} \mathrm{W}\right)$, located in the eastern region of Sergipe, in the municipality of Capela. This protected area was established to protect the springs of the Lagartixo stream and populations of the Endangered primate, Coimbra-Filho's titi monkey (Callicebus coimbrai). The MJ is composed of two forest fragments, however, the data collection was conducted only in the larger one ( 522 ha). Its matrix is composed of sugar cane and ca. 250 settlement families (urban areas). Both areas exhibited similar climatic conditions, with a dry period between September and March and rainy season between April and August. The historical mean annual rainfall at FT (2000-2010) was $127 \pm 79 \mathrm{~mm} / \mathrm{month}$ and at MJ (2003-2011) was $112 \pm 100 \mathrm{~mm}$. 


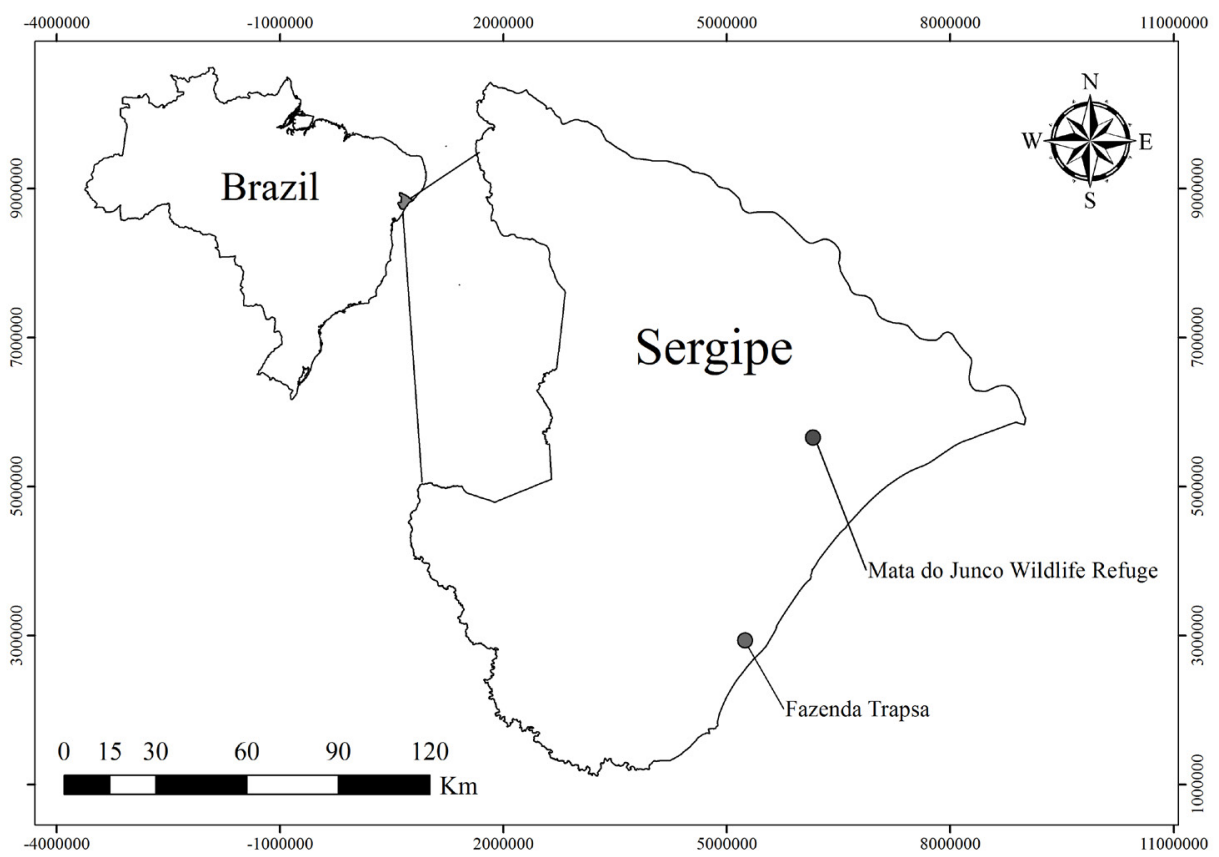

Figure 1. Map showing the two study sites in the Brazilian state of Sergipe.

\section{Sampling protocol}

We established 10 plots of 0.01 ha $(1 \mathrm{~m} \mathrm{x} 100 \mathrm{~m})$ in each site. At FT, the plots were distributed according to the size of the fragment: one plot in each of the two smaller fragments $(\leq 15 \geq 50 \mathrm{ha})$ and two plots in each of the four larger ones $(>50$ ha). At MJ plots were randomly distributed throughout the fragment. The plots were installed with a minimum distance of $500 \mathrm{~m}$ between them, in order to obtain samples of different vegetation types and avoid pseudo-replication. Within these plots, from January to March, 2013, we measured the diameter at breast height (dbh) of all trees with dbh $\geq 2.5 \mathrm{~cm}$ (Gentry 1982) and lianas with dbh $\geq 1.0 \mathrm{~cm}$ (Gerwing et al. 2006), and also the height of the trees. Individuals with multiple trunks had their dbh taken separately and added afterwards. Only lianas rooted within the plots were recorded.

The delimitation of plant families followed APG III (Angiosperm Phylogeny Group 2009) and the identification of the species was based on literature, comparisons with identified material in JPB herbarium, field guides for lianas (Buril et al. 2011; García-González and Alves 2011, 2012) and photos of the types online. The collected material was deposited in Herbarium JPB, at the Federal University of Paraíba, Brazil. 


\section{Data analysis}

Sampling coverage (Chao and Jost 2012), a measure of sample completeness, giving the proportion of the total number of individuals in a community that belong to the species represented in the sample, was calculated before statistical analysis. It was verified that in both FT $(82 \%)$ and $\mathrm{MJ}(82 \%)$ the sampling coverage was more than $80 \%$.

Absolute Density (AbsDe), Absolute Frequency (AbsFr), Absolute Dominance (AbsDo), Relative Density (RelDe), Relative Frequency (RelFr), Relative Dominance (RelDo) and Importance Value Index (IVI), were calculated for each species (MuellerDoimbois and Ellenberg 1974) in both floristic components (trees and lianas) in both sites. Also the total Basal area of trees and lianas in each site was estimated. These analyses were performed in the statistical software FITOPAC 2.1.2 (Shepherd 2006).

In order to verify differences between study sites, the density, frequency, dominance and basal area of trees and lianas were compared using one-way ANOVA. The data from all fragments at FT were used as a unique sample unit. All analyses were performed in the statistical software SPSS v. 21 (IBM Corporation Inc. 2012). Statistical significance level was set at $p<0.05$.

\section{RESULTS}

A total of 353 trees and 94 lianas in FT, and 154 trees and 33 lianas in MJ were sampled.

\section{Trees}

FT presented greater density of trees than MJ (3,530 ind/ha vs. 1,540 ind/ha: $F=27.785, p<0.001)$. The mean dbh was lower in FT $(6.9 \pm 6.0 \mathrm{~cm} v s .10 .6 \pm 9.7 \mathrm{~cm}$ : $F=10.353, p<0.001)$, whereas MJ showed higher mean height $(10.7 \pm 5.1 \mathrm{~m})$ when compared with FT $(8.3 \pm 6 \mathrm{~m})(F=13.462, p<0.001)$. Both MJ $\left(21.2 \mathrm{~m}^{2} / \mathrm{ha}\right)$ and FT $(39.5$ $\mathrm{m}^{2} /$ ha) presented similar basal area $(F=1.471, p=0.241)$.

The phytosociological importance of Eschweilera ovata (Lecythidaceae) at FT was the result of a higher density of individuals in the site, with $18.4 \%$ of total IVI (Table 1). All other species with high IVI, Tapirira guianensis (Anacardiaceae), Poecilanthe parviflora (Fabaceae), Inga capitata (Fabaceae) and Guettarda virbunoides (Rubiaceae), were characterized by high density ( 56 individual/ha). At MJ the species with the highest IVI was also Eschweilera ovata (60.23), which was characterized by high density, frequency and dominance (Table 1). The second highest IVI (36.95) at MJ was Luehea ochrophylla (Malvaceae), due mainly to the basal area of sampled individuals. At this site, other species with high values of IVI were Ocotea canaliculata 
(Lauraceae), Pouteria bangii (Burseraceae), Byrsonima sericea (Malpighiaceae), Campomanesia dichotoma (Myrtaceae), Protium heptaphyllum (Burseraceae), Erythroxylum squamatum (Erythroxylaceae) and Schefflera morototoni (Araliaceae) (Table 1).

Table 1. Phytosociological parameters of sampled tree species at the Fazenda Trapsa, Itaporanga d'ajuda, and Mata do Junco Wildlife Refuge, Capela, Sergipe, Brazil, arranged by decreasing IVI. (AbsDe = absolute density (ind./ha $\left.{ }^{-1}\right) ;$ RelDe = relative density (\%); $\mathrm{AbsFr}=$ absolute frequency; $\operatorname{RelFr}=$ relative frequency $(\%) ; \mathrm{AbsDo}=$ absolute dominance $\left(\mathrm{m}^{2} / \mathrm{ha}^{-1}\right)$; RelDo = relative dominance; IVI = importance value index $)$.

\begin{tabular}{|c|c|c|c|c|c|c|c|}
\hline Species & AbsDe & RelDe & AbsFr & RelFr & AbsDo & RelDo & IVI \\
\hline \multicolumn{8}{|l|}{ Fazenda Trapsa } \\
\hline $\begin{array}{l}\text { Eschweilera ovata (Cambess.) Mart. ex } \\
\text { Miers }\end{array}$ & 330.00 & $25 \cdot 38$ & 90 & 16.67 & 1.91 & 12.99 & 55.04 \\
\hline Tapirira guianensis Aubl. & 80.00 & 6.15 & 50 & 9.26 & $4 \cdot 48$ & 30.39 & 45.80 \\
\hline Poecilanthe parviflora Benth. & 230.0 & 17.69 & 60 & 11.11 & 1.37 & $9 \cdot 32$ & 38.13 \\
\hline Inga capitata Desv. & 130.0 & 10.00 & 50 & 9.26 & 1.52 & 10.33 & 29.59 \\
\hline Guettarda virbunoides Cham. \& Schltdl. & 120.0 & 9.23 & 60 & 11.11 & 1.28 & 8.71 & 29.06 \\
\hline $\begin{array}{l}\text { Pogonophora schomburgkiana Miers. ex } \\
\text { Benth. }\end{array}$ & 110.0 & 8.46 & 70 & 12.96 & 0.39 & 2.62 & 24.05 \\
\hline Manilkara salzmannii (A.DC.) H.J.Lam & 60.00 & 4.62 & 40 & 7.41 & 1.21 & 8.23 & 20.25 \\
\hline $\begin{array}{l}\text { Stryphnodendron pulcherrium (Willd.) } \\
\text { Hochr. }\end{array}$ & 50.00 & 3.85 & 50 & 9.26 & 1.04 & 7.03 & 20.14 \\
\hline Pouteria bangii (Rusby) T.D.Penn. & 80.00 & 6.15 & 60 & 11.11 & 0.30 & 2.06 & 19.33 \\
\hline \multirow[t]{2}{*}{ Attalea cf. funifera Mart. } & 110.0 & 8.46 & 10 & 1.85 & 1.22 & 8.30 & 18.61 \\
\hline & 1300.0 & 100 & 540 & 100 & 14.72 & 100 & 300.0 \\
\hline \multicolumn{8}{|l|}{ Mata do Junco Wildlife Refuge } \\
\hline $\begin{array}{l}\text { Eschweilera ovata ovata (Cambess.) Mart. } \\
\text { ex Miers }\end{array}$ & 210.0 & 25.61 & 60 & $13 \cdot 95$ & $3 \cdot 35$ & 20.70 & 60.26 \\
\hline Luehea ochrophylla Mart. & 20.00 & 2.44 & 10 & 2.33 & 5.21 & 32.18 & 36.95 \\
\hline Ocotea canaliculata (Rich.) Mez & 80.00 & $9 \cdot 76$ & 50 & 11.63 & 1.84 & 11.38 & 32.76 \\
\hline Pouteria bangii (Rusby) T.D.Penn. & 110.0 & $13 \cdot 41$ & 50 & 11.63 & 1.20 & $7 \cdot 40$ & 32.45 \\
\hline Byrsonima sericea DC. & 50.00 & 6.10 & 40 & $9 \cdot 30$ & 1.82 & 11.23 & 26.63 \\
\hline $\begin{array}{l}\text { Campomanesia dichotoma (O.Berg.) } \\
\text { Mattos }\end{array}$ & 70.00 & 8.54 & 40 & $9 \cdot 30$ & 1.32 & 8.18 & 26.01 \\
\hline Protium heptaphyllum (Aubl.) Marchand & 70.00 & 8.54 & 60 & $13 \cdot 95$ & 0.27 & 1.66 & 24.15 \\
\hline Erythroxylum squamatum Sw. & 90.00 & 10.98 & 40 & $9 \cdot 30$ & 0.33 & 2.05 & 22.33 \\
\hline Schefflera morototoni (Aubl.) Maguire et al. & 50.00 & 6.10 & 50 & 11.63 & 0.56 & $3 \cdot 45$ & 21.18 \\
\hline \multirow[t]{2}{*}{ Miconia prasina (Sw.) DC. } & 70.00 & 8.54 & 30 & 6.98 & 0.29 & 1.77 & 17.28 \\
\hline & 820.0 & 100 & 430 & 100 & 16.19 & 100 & 300.0 \\
\hline
\end{tabular}




\section{Lianas}

The density of lianas at FT was almost three times higher (940 ind./ha) than at MJ (366.6 ind./ha) $(F=6.612, p<0.05)$. The mean dbh for lianas at FT $(1.36 \pm 0.57$ $\mathrm{cm})$ was lower than that observed at MJ $(3.03 \pm 2.25 \mathrm{~cm})(F=8.740, p<0.001)$. The basal area of lianas sampled at MJ was similar between sites $\left(3.6 \mathrm{~cm}^{2} / \mathrm{ha}\right)$ and higher than at FT $\left(1.6 \mathrm{~cm}^{2} / \mathrm{ha}\right)(F=0.360, p=0.556)$.

At FT, Adenocalymma comosum had the highest IVI (93.72), followed by Coccoloba lucidula (47.37), both characterized by high densities. Coccoloba parimensis, Davilla kunthii, Cissus sp., Bonamia burchelli and Sparattanthelium botocudorum presented IVIs ranging between 11 and 19 (Table 2). Davilla kunthii presented the highest IVI (40.70) at MJ (Table 2), and Morphotype 4, with a higher basal area, an IVI of 39.77. The species with the $3^{\text {rd }}$ highest IVI (38.67), Banisteriopsis nummifera, exhibited a density of $15.1 /$ ha, Coccoloba parimensis and C. lucidula had a similar IVI and density.

Table 2. Phytosociological parameters of sampled liana species at Fazenda Trapsa, Itaporanga d'Ajuda, and Mata do Junco Wildlife Refuge, Capela, Sergipe, Brazil, arranged by decreasing IVI. (AbsDe = absolute density (ind./ha-1); RelDe = relative density (\%); $\mathrm{AbsFr}=$ absolute frequency; $\mathrm{RelFr}=$ relative frequency $(\%) ; \mathrm{AbsDo}=$ absolute dominance $\left(\mathrm{m}^{2} / \mathrm{ha}^{-1}\right) ;$ RelDo = relative dominance; IVI = importance value index $)$.

\begin{tabular}{lccccccc}
\hline Species & AbsDe & RelDe & AbsFr & RelFr & AbsDo & RelDo & IVI \\
\hline Fazenda Trapsa & & & & & & & \\
Adenocalymma comosum (Cham.) DC. & 420.0 & 44.68 & 90 & 22.50 & 0.04 & 26.54 & 93.72 \\
Coccoloba lucidula Benth. & 150.0 & 15.96 & 40 & 10.00 & 0.03 & 21.41 & 47.37 \\
Coccoloba laevis Benth. & 50.00 & 5.32 & 20 & 5.00 & 0.02 & 11.86 & 22.18 \\
Coccoloba parimensis Benth. & 30.00 & 3.19 & 30 & 7.50 & 0.01 & 7.64 & 18.33 \\
Davilla kunthii A.St.-Hill & 50.00 & 5.32 & 30 & 7.50 & 0.01 & 4.64 & 17.46 \\
Cissus sp. & 30.00 & 3.19 & 30 & 7.50 & 0.01 & 3.99 & 14.69 \\
Bonamia burchellii (Choisy) Hallier f. & 30.00 & 3.19 & 30 & 7.50 & 0.00 & 1.46 & 12.16 \\
Sparattanthelium botocudorum Mart. & 20.00 & 2.13 & 10 & 2.50 & 0.01 & 7.05 & 11.68 \\
Coccoloba paraensis Benth. & 30.00 & 3.19 & 10 & 2.50 & 0.01 & 3.25 & 8.94 \\
Phanera outimouta (Aubl.) L.P.Queiroz & 20.00 & 2.13 & 10 & 2.50 & 0.01 & 3.29 & 7.91 \\
Heteropterys nordestina Amorim & 20.00 & 2.13 & 10 & 2.50 & 0.00 & 1.41 & 6.03 \\
Morphotype 10 & 10.00 & 1.06 & 10 & 2.50 & 0.00 & 2.36 & 5.93 \\
Strychnos cf. bahiensis Krukoff \& Barneby & 10.00 & 1.06 & 10 & 2.50 & 0.00 & 1.25 & 4.81 \\
Bonamia maripoides Hallier f. & 10.00 & 1.06 & 10 & 2.50 & 0.00 & 0.70 & 4.27 \\
Morphotype 12 & 10.00 & 1.06 & 10 & 2.50 & 0.00 & 0.59 & 4.15 \\
Malpighiaceae sp.1 & 10.00 & 1.06 & 10 & 2.50 & 0.00 & 0.59 & 4.15 \\
Dioclea sp. & 10.00 & 1.06 & 10 & 2.50 & 0.00 & 0.49 & 4.05 \\
Coccoloba striata Benth. & 10.00 & 1.06 & 10 & 2.50 & 0.00 & 0.49 & 4.05 \\
Morphotype 15 & 10.00 & 1.06 & 10 & 2.50 & 0.00 & 0.49 & 4.05 \\
Leguminosae & 10.00 & 1.06 & 10 & 2.50 & 0.00 & 0.49 & 4.05 \\
\cline { 2 - 7 } & 940.0 & 100.0 & 400 & 100 & 0.15 & 100.0 & 300.0 \\
\hline
\end{tabular}




\begin{tabular}{lccccccc}
\hline Species & AbsDe & RelDe & AbsFr & RelFr & AbsDo & RelDo & IVI \\
\hline Mata do Junco Wildlife Refuge & & & & & & & \\
Davilla kunthii A.St.-Hill & 55.6 & 15.15 & 33.33 & 12.50 & 0.05 & 13.05 & 40.70 \\
Morphotype 4 & 11.1 & 3.03 & 11.11 & 4.17 & 0.13 & 32.57 & 39.77 \\
Banisteriopsis nummifera (A.Juss.) B.Gates & 55.6 & 15.15 & 33.33 & 12.50 & 0.04 & 11.02 & 38.67 \\
Coccoloba parimensis Benth. & 55.6 & 15.15 & 33.33 & 12.50 & 0.02 & 4.24 & 31.90 \\
Coccoloba lucidula Benth. & 55.6 & 15.15 & 33.33 & 12.50 & 0.02 & 4.01 & 31.66 \\
Desmoncus sp. & 22.2 & 6.06 & 11.11 & 4.17 & 0.04 & 10.45 & 20.67 \\
Bignoniaceae sp. 1 & 11.1 & 3.03 & 11.11 & 4.17 & 0.03 & 6.28 & 13.48 \\
Sparattanthelium botocudorumyyyyyyyyyyyy Mart. & 11.1 & 3.03 & 11.11 & 4.17 & 0.02 & 6.05 & 13.25 \\
Bignoniaceae sp. 2 & 11.1 & 3.03 & 11.11 & 4.17 & 0.02 & 5.60 & 12.80 \\
Morphotype 8 & 11.1 & 3.03 & 11.11 & 4.17 & 0.01 & 2.49 & 9.69 \\
Serjania paucidentata DC. & 11.1 & 3.03 & 11.11 & 4.17 & 0.01 & 2.20 & 9.40 \\
Sapindaceae sp.1 & 11.1 & 3.03 & 11.11 & 4.17 & 0.00 & 1.04 & 8.24 \\
Odontadenia lutea (Vell.) Markgr. & 11.1 & 3.03 & 11.11 & 4.17 & 0.00 & 0.26 & 7.46 \\
Morphotype 10 & 11.1 & 3.03 & 11.11 & 4.17 & 0.00 & 0.26 & 7.46 \\
Morphotype 5 & 11.1 & 3.03 & 11.11 & 4.17 & 0.00 & 0.26 & 7.46 \\
Morphotype 7 & 11.1 & 3.03 & 11.11 & 4.17 & 0.00 & 0.22 & 7.41 \\
\cline { 2 - 8 } & 366.7 & 100.0 & 266.6 & 100 & 0.39 & 100.0 & 300.0 \\
\hline
\end{tabular}

\section{DISCUSSION}

Our findings demonstrated that the sites presented different structural conditions in their habitats. Overall, FT presented a higher density of trees and lianas. In contrast, trees and lianas in MJ were taller and larger. Such variation between sites could be explained by landscape differences. For example, ArroyoRodríguez et al. (2009) evaluated the density of tree species in Mexican coastal forest fragments of different sizes embedded in varied landscapes. They observed that in different-sized forest patches, the number of tree species increased with patch size, but only in $<5$-ha fragments. Above this threshold of patch size, the number of species remained without significant changes. Even evaluating the mosaic of FT as whole, the results of this study reflects a strong influence of logging and edge effect in each fragment sampled. However, it is necessary to evaluate other fragments and insert more variables of landscape such as forest cover, connectivity, fragment sizes and/or total area of forest edge around the sites (Arroyo-Rodríguez et al. 2013) to confirm this hypothesis.

The trees and lianas measured in this study varied between sites. The tallest and largest trees and lianas were found in MJ. Besides the differences in landscape, $\mathrm{MJ}$ is a protected area already implemented, and protected areas tend to present less disturbed forests and the presence of tall and large trees and lianas (Scherer et al. 2005). On the other side, disturbed sites, such as the forest fragments of FT, appear to reveal a homogenization of the vegetation structure, smaller trees and abundance 
of pioneer species. FT has suffered with marked anthropogenic disturbances ca. 20 years ago, and presents a high number of pioneer species (Souza-Alves et al. 2014). Furthermore, lianas and pioneer trees have similar life history traits (light demand, rapid growth and high seed production) and, lianas tend to reduce competition for resources between pioneer and non-pioneer species, causing a reduction on the survival of non-pioneer trees (Schnitzer and Carson 2001). Fire, selective and indiscriminate logging, cattle, and hunt are human activities observed in the area during the study period. Thereby, is feasible to believe that these anthropic events and the presence of pioneer tree species in FT had contributed to the low number of large trees and lianas.

The basal area of trees in both FT and MJ are within the variation expected for tropical forest (20 a $45 \mathrm{~m}^{2} /$ ha: Durigan 2003), although much below that recorded for the Atlantic forest in southern Bahia, $45.6 \mathrm{~m}^{2}$ for trees with $\mathrm{dbh} \geq 5 \mathrm{~cm}$ (Thomas et al. 2008). It is noteworthy, however, that the southern Bahia forests are among the most conserved and diverse areas of the Atlantic Forest. The higher value of dbh exhibited in FT was a result of the sum of the average diameters of the trees, better distributed in all classes, rather than the concentration of trees within large dbh as in MJ.

The tree species with highest IVI in both areas was E. ovata. However, in FT, the individuals were more frequent and with higher density. In the region where FT is inserted, $E$. ovata is used in various ways, in the manufacture of tools, as a support for roofing, and in fences, which hinders the growth of individuals of the species. On the other hand, MJ has not suffered severe disturbance recently, thus facilitating the maintenance and growth of the tree individuals within the area. The sum of the IVIs of the first three species in each area did not reach $50 \%$ of the total, however, were similar and close to 50\%, indicating that both areas suffered disturbances in the past.

In relation to the lianas, Adenocalymma comosum presented an increase on its importance value at FT. The importance of the genus Coccoloba in both areas should be highlighted. In FT, three species of Coccoloba (C. ludicula, C. laevis and C. parimensis) were among the top five species, with almost $30 \%$ of the overall IVI. Similarly, in MJ, C. parimensis and C. lucidula exhibited high IVI in relation to the total. High values of IVI for species of this genus can be linked to two hypotheses (García-González 2011): (i) that the hiperabundance could be an influence of the amount of treefall gaps found within the fragments, due to the strong winds coming from the coast, and (ii) their fruit type has facilitated the species dispersion. In this study, we can infer that the first hypothesis could be occurring at FT, due to its high degree of disturbance (i.e., logging and edge effect), presence of treefall gaps, and also because of its proximity to the coast $(8 \mathrm{~km})$. The second hypothesis appears to be occurring in MJ, where we observed the two primate species present in the area, Callithrix jacchus and Callicebus coimbrai (Chagas, 2015), which are considered potentially good dispersants of seeds (Castro et al. 2003; Baião et al. 2015), consuming fruits of $C$. lucidula and $C$. parimensis. 


\section{CONCLUSION}

MJ presents a better level of conservation, with taller trees with larger dbh. In contrary, FT presented characteristics of areas in the initial stages of regeneration, with lower average height and reduced basal area. In addition, the high density of lianas and high diversity of pioneer tree species, logging and tree fall gaps are evident in FT. However, other factors, not measured in this study, such as the size and shape of the fragments, surrounding landscape and proximity to other fragments can also have influence on the composition and diversity of the fragments, especially in more fragmented areas as FT. Even though the two sites present different structural conditions, both shelter medium and large mammals such as Callicebus coimbrai, Sapajus xanthosternos, Bradypus torquatus, Mazama mazama, Puma concolor, Cerdocion thous, Hydrochaeris hydrochaeris (Chagas et al. 2011). These species depend on exclusive forest conditions to survive, and these fragments can also act as stepping stones or ecological corridors of biodiversity in the region. Thus, the conservation and development of management strategies for these habitats, such as the creation of protected areas, are essential to maintain and increase the diversity of the local fauna and flora.

\section{AUTHOR'S CONTRIBUTIONS}

Data collection: JPS-A; Data analysis: JPS-A; Manuscript writing: JPS-A, MRVB and WWT.

\section{ACKNOWLEDGMENTS}

We would like to thanks Ary Ferreira, owner of the Fazenda Trapsa, José Elias (Boía) and his family, Adriano Rodrigues (Xinxinho) and Marcelo Silva, for their assistance during the fieldwork. We are also grateful to the Environment Secretariat of the State of Sergipe (SEMARH) for providing additional logistic support and to Stephen Ferrari for his contribution on the initial draft of the manuscript. JPS-A is grateful to CAPES for the scholarship during his PhD course. Currently JPS-A is supported by CAPES/ PNPD (Postdoctoral Fellowship: Process no. 88882.306330/2018-1) and FACEPE (BCT-0025-2.05/17). MRVB was funded by CNPq (Processes no. 307648/2010-9 and $562310 / 2010-0)$. This study was financed in part by the International Primatological Society, the National Science Foundation - USA (DEB-0946618), and by the Coordenação de Aperfeiçoamento de Pessoal de Nível Superior-Brasil (CAPES) Finance Code oo1. 


\section{REFERENCES}

Angiosperm Phylogeny Group. 2009. An update of the Angiosperm Phylogeny Group classification for the orders and families of flowering plants: APG III. Botanical Journal of the Linnean Society, 161:105-121.

Arroyo-Rodríguez V, Cuestal-del-Moral E, Mandujano S, Chapman C, Reyna-Hurtado R, Fahrig L. 2013. Assessing habitat fragmentation effects for primates: The importance of evaluating questions at the correct scale. In: Marsh LK, Chapman CA (Eds), Primates in Fragments: Complexity and Resilience, $2^{\text {nd }}$ Edition. New York: Springer, New York, USA, p. 13-28.

Arroyo-Rodríguez V, Pineda E, Escobar F, Benítez-Malvido J. 2009. Value of small patches in the conservation of plant-species diversity in highly fragmented rainforest. Conservation Biology, 23:729-739.

Baião SA, Correia FB, Ferrari SF. 2015. Dietary differences have contrasting effects on the seed dispersal potential of the titi monkey Callicebus coimbrai in north-eastern Brazil. Journal of Tropical Ecology, 31(2):175-181.

Bell KE, Donnelly MA. 2006. Influence of forest fragmentation on community structure of frogs and lizards in northeastern Costa Rica. Conservation Biology, 20(6):1750-176o.

Broadbent EN, Asner GP, Keller M, Knapp DE, Oliveira PJ, Silva JN. 2008. Forest fragmentation and edge effects from deforestation and selective logging in the Brazilian Amazon. Biological Conservation, 141(7):1745-1757.

Buril MT, García-González J, Alves M. 2011. Convolvulaceae of Northeast Brazil. Environmental and Conservation Program, The Field Museum, Chicago. Rapid Color Guide \#293.

Castro CSS, Marques AAB, Izar P, Oliveira AC, Lopes MA. 2003. The role of primates as seed dispersers in the vegetation structure of tropical forests. Neotropical Primates, 11:125-127.

Chagas RRD, Santos Junior EM, Souza-Alves JP, Ferrari SF. 2011. Fazenda Trapsa, um refúgio de diversidade de mamíferos de médio e grande porte em Sergipe, Nordeste do Brasil. Revista Nordestina de Biologia, 19(2):35-43.

Chagas RRD. 2015. Ecologia, Comportamento e Associação Interespecífica de Callicebus coimbrai e Callithrix jacchus, no Refúgio da Vida Silvestre Mata do Junco, Sergipe, Brasil. Universidade Federal da Paraíba, 147 p. 
Chao A, Jost L. 2012. Coverage-based rarefaction and extrapolation: standardizing samples by completeness rather than size. Ecology, 93(12), 2533-2547.

Felfili JM, Rezende RP. 2003. Conceitos e métodos em fitossociologia. Comunicações Técnicas. Florestais. Volume 5. Brasília: Universidade de Brasília, Departamento de Engenharia Florestal, 68 p.

Flora do Brasil 2020 under construction. Jardim Botânico do Rio de Janeiro. Available at: <http://floradobrasil.jbrj.gov.br/ >. Accessed on: 20 May 2019

Galetti M, Dirzo R. 2013. Ecological and evolutionary consequences of living in a defaunated world. Biological Conservation, 163:1-6.

García-González J, Alves M. 2011. Common lianas, Atlantic Rain Forest, Igarassu, Pernambuco, Brazil: Lianas stems of the Usina São José. Environmental and Conservation Program, The Field Museum, Chicago. Rapid Color Guide \#283.

García-González J, Alves M. 2012. Trepadeiras e Lianas da Usina São José, Mata Atlântica, Pernambuco, Brasil: Trepadeiras e Lianas da Mata Atlântica. Environmental and Conservation Program, The Field Museum, Chicago. Rapid Color Guide \#305.

García-González JD. 2011. Diversidade e abundância de lianas em uma área de Floresta Atlântica semidecidual ao Norte do Estado de Pernambuco. Dissertação de Mestrado. Universidade Federal de Pernambuco.

Gentry AH. 1982. Patterns of neotropical plant species diversity. Evolutionary Biology, $15: 1-84$.

Gerwing JJ, SchnitzerSA, Burham RJ, Bongers F, Chave J, DeWalt SJ, Ewango CEN, Foster R, Kenfack D, Martínez-Ramos M, Parren M, Parthasarathy N, Pérez-Salicrup DR, Putz FE, Thomas DW. 2006. A standard protocol for liana censuses. Biotropica, 38:256-261.

Goerck JM. 1997. Patterns of rarity in the birds of the Atlantic forest of Brazil. Conservation Biology, 11(1): 112-118.

Haddad NM, Brudvig LA, Clobert J, Davies KF, Gonzalez A, Holt RD, ... Cook WM. 2015. Habitat fragmentation and its lasting impact on Earth's ecosystems. Science Advances, 1(2):e1500052.

Joly CA, Metzger JP, Tabarelli M. 2014. Experiences from the Brazilian Atlantic Forest: ecological findings and conservation initiatives. New Phytologist, 204(3):459-473. 
Kobayashi S, Langguth AB. 1999. A new species of titi monkey, Callicebus Thomas, from north-eastern Brazil (Primates, Cebidae). Revista Brasileira de Zooogia, 16:531551.

Kurten E. 2013. Cascading effects of contemporaneous defaunation on tropical forest communities. Biological Conservation, 163:22-32.

Laurance WF. 2010. Habitat destruction: death by a thousand cuts. Conservation biology for all, 1(9): 73-88.

Melo FP, Arroyo-Rodríguez V, Fahrig L, Martínez-Ramos M, Tabarelli M. 2013. On the hope for biodiversity-friendly tropical landscapes. Trends in Ecology $\mathcal{E}$ Evolution, 28(8):462-468.

Melo FPL, Lemire D, Tabarelli M. 2007. Extirpation of large-seeded seedlings from the edge of a large Brazilian Atlantic forest fragment. Ecoscience, 14:124- 129.

Mittermeier R, Gil PR, Hoffmann M, Pilgrim J, Brooks T, Mittermeier CG, Lamoreux J, Fonseca GAB, Seligmann PA, Ford H. 2004. Hotspots Revisited - Eath's biologically richest and most endangered terrestrial ecorregions. International Conservaion, Washington D.C.

Mueller-Dombois D, Ellenberg H. 1974. Aims and methods of vegetation ecology. Willey \& Sons. New York, 547 p.

Pardini R, de Souza SM, Braga-Neto R, Metzger JP. 2005. The role of forest structure, fragment size and corridors in maintaining small mammal abundance and diversity in an Atlantic forest landscape. Biological Conservation, 124(2):253-266.

Parker TA, Stotz DF, Fitzpatrick JW. 1996. Ecological and distribution databases. In: Stotz DF, Fitzpatrick JW, Parker TA, Moskovits DK (Eds.), Neotropical birds: ecology and conservation. Chicago: University of Chicago Press. pp. 131-436.

Rands MR, Adams WM, Bennun L, Butchart SH, Clements A, Coomes D, ... Sutherland WJ. 2010. Biodiversity conservation: challenges beyond 2010. Science, 329(5997):12981303.

Rezende CL, Scarano FR, Assad ED, Joly CA, Metzger JP, Strassburg BBN, ... Mittermeier RA. 2018. From hotspot to hopespot: An opportunity for the Brazilian Atlantic Forest. Perspectives in Ecology and Conservation, 16(4):208-214. 
Santo-Silva E, Almeida WR, Melo FPL, Zickel CS, Tabarelli M. 2013. The nature of seedling assemblages in a fragmented tropical landscape: implications for forest regeneration. Biotropica, 45:386-394.

Scherer A, Maraschin-Silva F, Baptista LRM. 2005. Florística e estrutura do componente arbóreo de matas de Restinga arenosa no Parque Estadual de Itapuã, RS, Brasil. Acta Botânica Brasilica, 19(4):717-726.

Schnitzer SA, Carson WP. 2001. Treefall gaps and the maintenance of species diversity in a tropical forest. Ecology, 82:913-919.

Shepherd GJ. 2006. FITOPAC I. Manual do Usuário. Universidade Estadual de Campinas, Campinas.

Silva JMC, Casteleti CHM. 2003. Status of the biodiversity of the Atlantic Forest of Brazil. In: Galindo-Leal C, Câmara IG (Eds), The Atlantic Forest of South America: biodiversity status, trends, and outlook. Center for Applied Biodiversity Science and Island Press, Washington DC., p. 43-59.

Souza-Alves JP, Ferrari SF, Barbosa MRV, Thomas WW. 2014. Diversity of trees and lianas in two sites in the coastal Atlantic Forest of Sergipe, northeastern Brazil. Check List, 10:709.

Stotz DF, Fitzpatrick JW, Parker TA, Moskovits DK (Eds.), 1996. Neotropical birds: ecology and conservation. Chicago: University of Chicago Press. 478 p.

Thomas WW, Carvalho AMV, Amorim AM, Hanks JG, Santos TS. 2008. Diversity of woody plants in the Atlantic Coastal Forest of Southern Bahia, Brazil. In: Thomas WW (Ed), The Atlantic Coastal Forest of Northeastern Brazil. The New York Botanical Garden Press, New York, p. 21-66.

Whitmore TC. 1998. Potential impact of climatic change on tropical rain forest seedlings and forest regeneration. In: Markham A (Ed), Potential Impacts of Climate Change on Tropical Forest Ecosystems. Netherlands: Springer, Dordrecht, pp. 289298. 